\title{
The Axiology of Pancasila in the Reconstruction of Legal Culture in Indonesia
}

\author{
Junaedi \\ Postgraduate of Law Studies, Universitas Swadaya Gunungjati Cirebon, Indonesia \\ E-mail : junaedi.ugj@gmail.com
}

How to cite : Junaedi, Junaedi. (2019). The The Axiology of Pancasila in the Reconstruction of Legal Culture in Indonesia. UNIFIKASI : Jurnal IImu Hukum, 6(1), 7-13. DOI : 10.25134/unifikasi.v6i1.1815

Submitted : 10-01-2019 Revised : 10-06-2019 Accepted : 19-08-2019

\begin{abstract}
Pancasila is the result of a consensus with the founding fathers of the nation. Pancasila as a view of life and an ideology of the Unitary State of the Republic of Indonesia provides direction and goal to create an equitable and prosperous community. This study aims to analyze how the Axiology of Pancasila in the Reconstruction of Legal Culture in Indonesia. The method used in this study was normative juridical. The results showed that Pancasila is listed in the Preamble of the 1945 Constitution as a state constitution that needs to be actualized in daily life. Consequently, the values of Pancasila as a result of the crystallization of the nation's culture that is multiculturalism must be reflected in the mindset, creativity, taste and behavior of Indonesian people. In the field of law, the values of Pancasila must be reflected in law enforcement with a sense of social justice for all Indonesian people. Hence, the legal culture characterized by the values of Pancasila needs to be actualized in order to realize national legal awareness in an effort to develop laws that protect and provide a sense of justice for all Indonesian people.
\end{abstract}

Keywords: The Values of Pancasila; Values and Legal Culture

\section{Aksiologi Pancasila dalam Rekonstruksi Budaya Hukum di Indonesia}

Abstrak : Pancasila adalah hasil konsensus bersama para pendiri bangsa Indonesia. Pancasila sebagai ideologi dan pandangan hidup bangsa memberikan arah dan tujuan untuk membangun masyarakat Indonesia yang adil dan makmur dalam NKRI. Tujuan penelitian ini adalah bagaimana Aksiologi Pancasila dalam Rekonstruksi Budaya Hukum Di Indonesia. Metode penelitian yang digunakan dalam penelitian ini adalah yuridis normatif. Hasil penelitian yaitu Pancasila tercantum dalam Pembukaan UUD 1945 sebagai konsitusi Negara yang perlu diaktualisasikan dalam kehidupan sehari-hari. Sehingga memberikan konsekuensi, bahwa nilai-nilai Pancasila sebagai hasil kristalisasi budaya bangsa yang bersifat multikulturalisme harus tercermin dalam pola pikir, cipta rasa dan tingkah laku masyarakat Indonesia. Dalam bidang hukum, nilai-nilai Pancasila harus tercermin dalam penegakan hukum yang berwatak rasa keadilan sosial bagi seluruh rakyat Indonesia. Sehingga budaya hukum yang berkarakter nilai-nilai Pancasila perlu diaktualisasikan demi terwujudya kesadaran hukum nasional dalam upaya membangun hukum yang mengayomi dan memberikan rasa keadilan bagi seluruh rakyat Indonesia.

Kata Kunci: Nilai Pancasila, Nilai, dan Budaya Hukum

\section{INTRODUCTION}

The proclamation of independence is a result of the struggle to realize the ideals of Indonesian people to live in a better, equitable and prosperous national life. The basic value contained in the proclamation is a struggle that acts as a trigger for the rise of the spirit of the nation in an effort to develop all fields, including ideology, politics, law, economics, social, culture, government, security, and religion. After the independence, Indonesia has a shared concept concerning fundamental matters for the survival, wholeness, and glory of the nation. In a speech at the United Nations on September 30, 1960, President Soekarno introduced Pancasila to the world as the conception and ideal of the nation. Pancasila contains values that are in accordance with the nationality conditions in dealing with various challenges and reflect the character of the nation. ${ }^{1}$

\footnotetext{
${ }^{1}$ Tim Kerja 2012,Sosialisasi MPR, Empat Pilar Kehidupan Berbangsa dan Bernegara, Sekretaris Jendral MPR, Jakarta,9.
} 
In the history, it cannot be denied that the binding element of the nation's harmony is the values that grow, live and develop in community's life. These values have become the impetus for achieving the expected goals. The crystallization of these values is the precepts listed in Pancasila. Pancasila as listed in the Preamble of the 1945 Constitution of the Republic of Indonesia has been accepted and determined as the basis of the State. In Pancasila, the personality and the view of life of the nation that have been tested for their truth and efficacy are listed. Thus, there will no any power that can separate Pancasila from the life of Indonesian people. ${ }^{2} \quad$ Before ratifying Pancasila as the basis of the state, the values contained in it have already existed in the customs and culture of Indonesian people, for example in its manifestations as the view of life, the identity, the way of life, the character as well as the philosophy of life. Thus, the values of Pancasila have already been integrated in Indonesian people life. Hence, the Indonesian nation is a "causa materialis" of Pancasila.

In the field of law, Pancasila is used as a source of positive law in Indonesia. Therefore, Pancasila as a national law guideline has a prismatic nature. This prismatic concept then lead to the creation of several guidelines as the basis for political work of national law, namely; 1) the laws in Indonesia must guarantee national integrity, and therefore, there should not be discriminatory laws that have the potential to disintegrate; 2) the laws must be developed democratically and nomocratically; 3 ) the laws must lead to the creation of social justice by providing special protection towards weak groups of people so that they are not allowed to compete freely; and 4) there should be no public law based on certain religious teachings since the laws must guarantee the tolerance of religious life. The state cannot formally enforce religious laws. In contrast, the state must facilitate citizens to carry out their religious teachings voluntarily so that conflicts or neglects will not occur. ${ }^{3}$

In the legal context, the issue of legal culture needs to be concerned. The legal culture in Indonesia is changing along with the changes in Indonesian community. Basically, the formation of a legal culture cannot be separated from cultural considerations and characteristics of the community. The legal culture growing in the community is an embodiment of the values which are the basis of the nation and the state. This condition has a significant effect on the final outcome of legal development. Therefore, various steps are needed to change the legal culture that can increase legal development in order to realize the ideals of the nation. As a manifestation in the life of the nation, the values of Pancasila are believed to be the basic values as well as the culmination of the nation's culture, soul and personality. Thus, it is reasonable to recognize the position of Pancasila as the philosophy of the Indonesian nation. Based on the description, the problem raised in this study is formulated to the following question: how is the Axiology of Pancasila in the Reconstruction of Legal Culture in Indonesia?

\section{RESEARCH METHODS}

The method used in this study was normative juridical (doctrinal). Meanwhile, the data used in this study were secondary data, including primary legal materials in the form of the 1945 Constitution and other legislations, as well as secondary legal materials in the form of journals, previous research studies and books.

\section{RESULTS AND DISCUSSION}

\section{The Conception of Value in Philosophy}

Speaking of values, we are faced with the issue of the will encouraging people to do an action. By analogism, value always starts from humans and their self-awareness. In other words, values are

\footnotetext{
${ }^{2}$ Siregar, Eddie, 2012, Pengantar dalam Empat Pilar Kehidupan Berbangsa dan Bernegara, Seketariat Jenderal MPR RI, Jakarta,3-4.

${ }^{3}$ Mahfud, Md, Moh, 2006, Membangun Politik, Menegakkan Konstitusi, LP3ES, Jakarta, 128
} 
what drive humans to want or do something. Therefore, value is related to choice. For humans, values are used as a basis, reason or motivation of their attitudes and behavior. In order to make the values operational or can be implemented, they must be expressed in the form of norms or rules. In this sense, value can be understood as the norm or standard that always directs humans to noble deeds in order to obtain happiness in their life. Thus, it is clear that value is something that is "guaranteed" as good. Hence, value is sought, wanted and fought for. ${ }^{4}$

In the "Dictionary of Sociology and Related Siences", it is stated that value is the believed capacity of any object to satisfy a human desire. Thus, value is essentially the nature or quality inherent in an object, not the object itself. If someone says that something contains value, it means that there is a quality inherent in it. ${ }^{5}$ Value is a quality causing something to be liked, desired or valued so that it is worth seeking by humans. Here, value is closely related to the value of goodness that attracts someone's desires. In the Enyclopedia of Philosophy, axiology is equated with Value ang Valuation. Thus, there are three types of Value ang Valuation, namely: (1) Value is used as an abstract noun. In a narrower sense, value is defined as nice, attractive and good. Meanwhile, in a broader sense, it includes all forms of obligation, truth, and holiness; (2) Value as a concrete noun. Value is often used for anything that has value as opposed to what is not good or valuable; and (3) Value is also used as a verb in expressing values, giving values and being valued. ${ }^{6}$

Value is basically an abstract conception found in human life concerning what is considered right and wrong, beautiful and not beautiful, as well as good and bad. Values related to right and wrong are called logic, values related to beautiful and not beautiful are called aesthetics, and values related to good and bad are called ethics. Values are accepted, confirmed and institutionalized in community in different ways. One of the ways to realize values is in the form of social norms. Further, norms become social regulations specializing in what is expected or what is permitted as well as how and to whom responsibility for an event and its consequences are laid. Values and norms that have been internalized within an individual will become the individual's frame of reference as ethical principles. These ethical principles then become the basis, orientation and guidance for us in overcoming various problems in establishing social relationships with others. These ethical principles also regulate and give meaning as well as unity to our personality in choosing our behavior, goals and lifestyle, and allow us to obtain a basis for justification and decision making for the actions we take.

Some values that are considered important include: the survival of individuals and groups, selfexperience, togetherness, appreciation and self-respect, personal abilities, personal matters, achievement and self-realization. Values related to people's self-esteem indicate the need for selfidentity, values related to living standards and income guarantees indicate the need and survival, values of success indicate personal things of an individual, and values of empathy indicates the need to love and togetherness. Hence, these values are closely related to facts. Yet, commitment to values cannot be placed on realistic operational tasks or goals since concrete resources are needed to achieve them. Besides, there is also a need to consider the effectiveness of measurable procedures and programs.

\section{The Values of Pancasila}

The values of Pancasila are a summary of the values of the nation as a whole and are general in nature. Since Pancasila is a summary of values that are general in nature, there has been an agreement set forth in the decree of the People's Consultative Assembly (MPR) in terms of its implementation. The ethical guideline is what we know as Eka Prasetya Panca Karsa or the Guideline for Living and Practicing Pancasila (P4). Basically, if these norms can be well implemented, there will be many ethical

\footnotetext{
${ }^{4}$ Bertens, K, 1983, Etika, Gramedia, Jakarta,139

${ }^{5}$ Kaelan, 2002,Pendidikan Pancasila, Paradigma, Yogyakrta, 174

${ }^{6}$ Edwards, (ed), 1967, The Encyclopedia of Philosophy, New York: Collier Macmilan Publishers, Volume 7, 137
} 
problems that have been resolved in our bureaucracy. In this guideline, human nature is known as a personal being and social creature. Thus, the key to the desired behavior is the willingness and ability of an individual to control himself and his interests in order to carry out his obligations as citizens. This attitude is pursued to carry out the precepts of the Pancasila, both as stand-alone principles or as a whole.

According to Notonagoro, the values of Pancasila include spiritual values that recognize material and vital values. The values of Pancasila incorporating in spiritual values also contain other values that are complete and harmonious, namely material values, vital values, truth values or aesthetics, virtues or moral values as well as holiness or religious values in which all of these values are systematic and hierarchical placing the first and the fifth precepts of Pancasila as the basis. Further, the values of Pancasila also have an objective and subjective nature. This view is in accordance with the multiculturalism of the nation and the Indonesian people. The objective values of Pancasila means that the precepts of Pancasila will remain throughout the life of the nation and the Indonesian people both in terms of customs, culture, religious life, etc. This is due to the fact that Pancasila contains an absolute relationship between human life, between humans and God, humans and their neighbors, and humans and nations. Thus, the values of Pancasila are objectives since they will never change. Meanwhile, the subjective values of Pancasila are the values arising from Indonesian people as a result of research and philosophical thinking. Therefore, Pancasila is stipulated as the most appropriate, the wisest, and the best philosophy of life for the nation. ${ }^{7}$

The values of Pancasila are basically rooted in the diversity or the multiculturalism of the nation and the Indonesian people in which the nature of the multiculturalism develops over time. Thus, it is reasonable if the values of Pancasila are very comprehensive with the characteristic of national identity and Indonesian people which is then outlined in the Preamble of the 1945 Constitution of the Republic of Indonesia. The fourth paragraph of the Preamble of the 1945 Constitution containing the five percepts of Pancasila describes the values of the nation and the Indonesian people summarized in a state constitution. Thus, Indonesian people have the right and obligation to actualize the values of Pancasila in their life. In this sense, the position of Indonesian people as citizens and as state administrators must be guided by the values of Pancasila. Redefining Pancasila means reaffirming the commitment that the values of Pancasila are the basis and ideology of the nation. Pancasila is not a mere concept of thought, but a set of values to be used as a guidance in various aspects of life. Thus, the values of Pancasila must be an ethical and moral foundation when we build political, government, and economic institutions as well as establish and enforce law, politic, social, culture and other various aspects of life.

Finally, the most basic values of Pancasila include the divine, humanitarian, unity, justice and community values as the philosophy of life of the nation. Further, Pancasila as the nation's view of life means that the values contained in Pancasila have been believed to be true and able to encourage Indonesian people to realize these values in their life. Pancasila is accepted as the basis of the State. It means that the values of Pancasila must always be the basis for any regulation and administration of the State. Indeed, this has been implemented by describing the values of Pancasila into the applicable legislations. ${ }^{8}$

\section{The Values of Pancasila in the Reconstruction of Legal Culture}

The term "legal culture" first appeared formally as a legal policy in Indonesia in the MPR Decree No. II/MPR/1998 concerning GBHN which states: "Development in the legal sector is directed

\footnotetext{
${ }^{7}$ Salam, Burhanudin,1998, Filsafat Pancasila, Rineka Cipta, Jakarta,42

${ }^{8}$ Wahana, Paulus, 2003, Filsafat Pancasila, Kanisius, Yogyakarta,65
} 
at the realization of a national legal system based on the Pancasila and the 1945 Constitution which includes the development of legal material, legal apparatus, legal facilities and infrastructure, and legal culture as a realization of the state of law that respects and upholds human rights to create orderly, safe, and peaceful community life." After the 1998 GBHN to the 2014-2019 RPJP, the legal culture is not a part of legal policy stated specifically so that it is not widely discussed as the main public discourse.

In his writing entitled Judicial Institutions and Legal Culture in Indonesia, Daniel S. Lev describes the legal system and legal culture. According to Lev, legal system focuses on procedures so that it does not explain how people solve their problems in their daily life. Meanwhile, legal culture is divided into procedural and substantive legal values. The procedural legal values describe the community and conflict management, while the substantive component of this legal culture consists of fundamental assumptions concerning resources distribution and utilization within the community. Legal culture is an important aspect to understand the differences existing between one legal system and another. Lawrence M. Friedman in his writing entitled The Legal System: A Social Science Perspective (1975) states that one of the components in a legal system, in addition to legal substance and legal structure, is legal culture. According to Friedman, legal culture is a constant social force in the form of social behavior and values operating the engine of a legal system to move forward or stop.

Consequently, even though legal substance in the form of legislations, government regulations or judges' decisions, legal structure in the form of organization, facilities and infrastructure as well as legal apparatus in a legal system is fairly good, but if it is not accompanied by a good legal culture, the legal system will not be able to be optimally applied. Therefore, it is believed that law enforcement will succeed if it is accompanied by firstly strengthening the legal culture. ${ }^{9}$

Further, the legal culture of the community tends to be influenced by the paternalistic attitude in the community. The community will pay more attention to the character or attitude shown by the government in front of them. Therefore, sincerity which is a precondition for a leader and leadership is considered important. In this case, the community must be guided by the mutually agreed values which constitute to the nation's view of life in order to realize such attitude. ${ }^{10}$ It means that Pancasila must be used as the basis of all fundamental arrangements of life. Thus, it can be said that Pancasila as the ideology and the basis of the State is a system of noble values which is ultimate and definitive. ${ }^{11}$ In order to create a discussion on Pancasila to be more authentic and functional, it is recommended to start the discussion with a concrete elaboration towards an order based on Pancasila since the hegemony of the state law has now entered the "era of order". Hence, it should be avoided approaching Pancasila as it was done in the past in which Pancasila was discussed ideologically-normatively and formally.

Pancasila as a legal ideal (rechtsidee) must be realized in the legal culture of the community because this legal ideal is within the ideals of Indonesian people in the form of ideas, tastes, aspirations, and thoughts. On the other hand, law is a reality in life related to the desired values and aims to serve those values. Legal ideals can also be defined as the construction of mind which is a necessity for directing the law to the expected ideals. As a legal ideal, Pancasila can have both constitutive and regulative functions. With its constitutive function, Pancasila becomes the basis of a legal system that gives meaning to the law. Thus, without the basis given by Pancasila, the law will lose its meaning as law. Meanwhile, with its regulative function, Pancasila determines whether a positive law as a product is fair or unfair. ${ }^{12}$ In its grounded dogmatic, cultural dimension should precede other dimensions since it contains a set of value system. Further, this value system becomes the basis for policy making and then

\footnotetext{
9 Azhari, Aidul Fitriciada, 2017, Kata Pengantar dalam Etika dan Budaya Hukum dalam Peradilan, Komisi Yudisial Republik Indonesia,4.

${ }^{10}$ Sutrisno, Endang,2007, Bunga Rampai Hukum dan Globalisasi, Genta Press, Yogyakarta, 96

${ }^{11}$ Tim Peneliti FH UGM dan FH Universitas Pancasila, 2006, pokok-Pokok Hasil Penelitian tentang Nilai-Nilai Pancasila Sebagai Dasar Pengembangan Ilmu Hukum Indonesia, Jakarta, 1

${ }^{12}$ Mahfud, Md, Moh,2006,Membangun Politik, Menegakkan Konstitusi, LP3ES, Jakarta,56
} 
followed by law making as a juridical guideline as well as code of conduct in everyday life which are expected to reflect the noble values possessed by the nation.

As a value, Pancasila contains a must to be implemented. Values are ideals that serve as motivation for all humans' attitudes, behavior, and actions. Since the founding fathers of the nation have explored, discovered and believed the importance of the values of Pancasila, they hope that all Indonesian people who have chosen the freedom to determine their life goals can support the realization of these values. Thus, in order to make these values able to attract people's attention, these values need to be formulated in a clear formula as the ideal goal of the nation. These values have been formally formulated and stipulated in the Preamble of the 1945 Constitution and become an ideal goal of Indonesian people. Formally, the values of Pancasila are values that must be accepted, supported and respected by all Indonesian people. The values of Pancasila outlined in the Preamble of the 1945 Constitution constitute legal and moral ideals which are the hopes and dreams of Indonesian people. The values of Pancasila, as the ideals of all Indonesian people, will be able to attract all Indonesian people to realize them in their attitudes and actions in everyday life. ${ }^{13}$

After understanding that the values of Pancasila are values that must be realized as well as become a guideline in our everyday life, we still need to formulate and organize the life system of Indonesian people to realize the values of Pancasila. For example, in promoting the unity of Indonesian people, we need to arrange and regulate interactions among citizens consisting of various ethnicities, groups, religions, and cultures. Likewise, in the field of law enforcement, we need to promote the community's obedience to the applicable rule of law. Thus, it is important to actualize the values of Pancasila in the nation's legal culture by developing people's awareness towards the noble values of Pancasila through workshops, symposiums, seminars, educational curricula, and coaching towards the state apparatus and Indonesian people. All of these activities must be done both formally and nonformal.

All in all, this legal system is bound to the ideal pattern which refers to the legal culture pattern that is expected to apply by certain community. This ideal pattern is the basic pattern reflected in various forms of conception both as a view of life, life ideals, legal ideals, as well as legal norms and behavior in which all of these conceptions are interrelated as a legal system. Political policy concerning legal development with a cultural approach was finally included in the GBHN. The "cultural" dimension was included by the MPR as a sub-system of legal development by stating that; The development of legal culture is directed to shape the attitudes and behavior of the community as well as the state administrators in accordance with the values and norms of Pancasila so that the legal culture is more internalized in people's life resulting in the increase level of legal awareness and obedience and human rights are increasingly respected and upheld. ${ }^{14}$

\section{CONCLUSION}

The values of Pancasila are basic human values that have been found in Indonesian people life. These basic values are moral values that can be a way of life for Indonesian people. In order to realize the values of Pancasila, an atmosphere of community life that supports the realization needs to be created so that the embodiment of the values of Pancasila becomes something that is expected by the community. The values of Pancasila which are the crystallization of the noble values of Indonesian people are the nation's culture used as the foundation in everyday life. In the field of law, the values of Pancasila are a paradigm for reconstructing the legal culture to realize social justice. Therefore, legal culture is an actualization of the values held by (a large part of) the community. Thus, legal culture is

\footnotetext{
${ }^{13}$ Moedjanto, G., dkk, 1987,Pancasila (Buku Panduan Mahasiswa), Gramedia, Jakarta,82-86

14 Sesse, Muh. Sudirman, 2013, Budaya Hukum Dan Implikasinya Terhadap Pembangunan Hukum Nasional, STAIN Parepare, Jurnal Hukum Diktum, Volume 11, Nomor 2, Juli 2013.176
} 
closely related to the mindset of the community. Hence, the development of a legal culture is aimed at creating peace and order and upholding the law characterized by honesty, truth and justice to realize legal certainty in order to promote national discipline.

\section{SUGGESTION}

By paying attention to the weaknesses in the formulation/legislation policy relating to the corporate criminal liability system in 124 (one hundred twenty four) special criminal legislations spread outside the Criminal Code, in order to overcome corporate criminal acts and national criminal law reform (penal reform), it is necessary to reorient and reformulate concerning the definition of corporation, the party that should bear criminal liability, classification/categorization of actions as corporate criminal acts, and the type of criminal sanctions against a corporation committing a criminal act.

\section{REFERENCES}

Azhari, Aidul Fitriciada. (2017). Kata Pengantar dalam Etika dan Budaya Hukum dalam Peradilan, Komisi Yudisial Republik Indonesia.

Bertens, K. (1983). Etika, Gramedia, Jakarta.

Djuneaidi, Oding. (2009) Esensi Manusia Dalam Filsafat Pancasila (Relevansinya Dalam Pembangunan Hukum Di Indonesia), FH. Uswagati, Cirebon, 2009.

Edwards, (ed). (1976) The Encyclopedia of Philosophy, New York: Collier Macmilan Publishers, Volume 7.

Kaelan. (2002). Pendidikan Pancasila, Paradigma, Yogyakrta, 2002.

Laurensius Arliman S, (2018). Perlindungan Hukum Bagi Anak Dalam Perspektif Pancasila Dan Bela Negara, UNIFIKASI : Jurnal Ilmu Hukum.5(1).

Mahfud, Md, Moh. (2006). Membangun Politik, Menegakkan Konstitusi, LP3ES, Jakarta.

Moedjanto, G., dkk. (1987). Pancasila (Buku Panduan Mahasiswa), Gramedia, Jakarta.

Pujiyono, (2012). Rekonstruksi sistem peradilan pidana indonesia dalam perspektif kemandirian kekuasaan kehakiman, Masalah-Masalah Hukum: 41(1).

Rahardjo, Pancasila. (2006). Hukum dan Ilmu Hukum, (Seminar Nasional dalam Rangka Dies Natalis ke-40 Universitas Pancasila), Jakarta.

Salam, Burhanudin. (1998). Filsafat Pancasila, Rineka Cipta, Jakarta.

Sesse, Muh. Sudirman. (2013). Budaya Hukum Dan Implikasinya Terhadap Pembangunan Hukum Nasional, STAIN Parepare, Jurnal Hukum Diktum, Volume 11, Nomor 2, Juli 2013.

Setiawan, Dian Alan. (2018). The Implication of Pancasila Values on the Renewal of Criminal Law in Indonesia. UNIFIKASI : Jurnal Ilmu Hukum, 5(2), 58-67.

Siregar, Eddie. (2012). Pengantar dalam Empat Pilar Kehidupan Berbangsa dan Bernegara, Seketariat Jenderal MPR RI, Jakarta.

Sutrisno, Endang. (2007). Bunga Rampai Hukum dan Globalisasi, Genta Press, Yogyakarta, 2007.

Tim Peneliti FH UGM dan FH Universitas Pancasila. (2006). Pokok-Pokok Hasil Penelitian tentang Nilai-Nilai Pancasila Sebagai Dasar Pengembangan Ilmu Hukum Indonesia, Jakarta.

Tim Kerja Sosialisasi MPR. (2012). Empat Pilar Kehidupan Berbangsa dan Bernegara, Sekretariat Jenderal MPR RI, Jakarta.

Wahana, Paulus. (2003). Filsafat Pancasila, Kanisius, Yogyakarta. 